\title{
Analysis on Emergency and Disaster Preparedness Level of Hospitality Industry in Palu and Gorontalo Cities
}

\author{
Avinia Ismiyati, Fatma Lestari* \\ Occupational Health \& Safety Department, Faculty of Public Health Universitas Indonesia, Depok 16424, West Java, \\ Indonesia
}

Corresponding Author Email: fatma@ui.ac.id

https://doi.org/10.18280/ijsse.100512

Received: 12 August 2020

Accepted: 9 October 2020

Keywords:

disaster management, emergency preparedness, hospitality industry, resilience

\begin{abstract}
Palu and Gorontalo cities are provincial capitals located on Sulawesi Island, Indonesia. In 2018, the city of Palu was hit by the earthquake that was followed by tsunami disaster and liquefaction, causing thousands of people to die and hundreds of thousands were displaced. These types of disasters and emergencies may also potentially strike Gorontalo City due to its geographic similarity to Palu City. Natural disasters affect workers and companies, including those working in the hospitality industry. Natural disasters are not the only cause of emergencies in the hospitality industry. Emergencies in this industry can also be caused by non-natural disasters, including by social disasters. This study aimed to assess the level of emergency and disaster preparedness in the hospitality sector in Palu and Gorontalo cities using a questionnaire adapted from the APEC tourism risk management and tourism resilience index. Focus Group Discussions and interviews were also performed to discuss the implementation of emergency and disaster management in the workplace. The results of the multiple correspondence analysis of emergency preparedness and disaster management factors in hotels in Palu shows that they are relatively closer to the moderate rating. Meanwhile, the same variables in Gorontalo are found to be in the low category. Based on these results, the participation of the private sector (hospitality industry) and the government is needed to build a good synergy in disaster risk reduction programs both locally and nationally.
\end{abstract}

\section{INTRODUCTION}

The tourism sector is the sector with the fastest economic growth in many countries around the world because this sector employs many people and opens many new jobs, especially for women, adolescents, migrant workers, and people living in rural areas [1]. However, this large number of workers also makes this industry prone to occupational hazards and risks, including those related to emergencies and disasters. Several incidents in the category of emergency have also been recorded in the tourism industry as occupational-related emergencies. These incidents include food poisoning, motor vehicle accidents, extreme weather, and fires [1]. In Indonesia, the tourism industry is a fast-growing industry and is a mainstay of the national economy. However, this industry is also vulnerable to natural hazards and man-made hazards. Data from the National Disaster Management Agency (Badan Nasional Penanggulangan Bencana, BNPB) in December 2018 show that 437 people died, 14,059 were injured, and 33,721 were displaced because of the tsunami in the tourism area of Banten [2]. Another tsunami, which hit Palu City, also makes 1,703 people died and greatly affects the tourism sector of the city [3].

The scope of the tourism industry, according to the ILO, include hotels, resorts, restaurants, tourist areas, travel agents, conference venues, and entertainment venues [1] of these, the hotels located in a tourism area is the one that attracts tourists, both domestically and internationally. Data released by the
Ministry of Tourism and Creative Industries in 2015 show that tourists tend to spend the largest amount of money (more than $40 \%$ ) on lodging such as for hotels and other accommodations [4]. Hotels can be affected by natural disasters and fires as exemplified by the situation after a major disaster striked Palu City in 2018. According to the report in the official Republika site based on the information provided by the Tourism Crisis Center (TCC), there were 250 hotel rooms affected by the earthquake and tsunami in Palu City [5]. Disasters can also have an impact on workers who might be injured or even died because of the disaster. One of the incidents in Palu City involves an engineering staff member at the Roa-Roa Hotel, Palu City, who fell from the 7th floor during the earthquake, which was then considered as an occupational accident by the Indonesian National Insurance for Employees (BPJS Ketenagakerjaan) [6]. Another city in the coastal area of Sulawesi Island, Gorontalo city, was also hit by a natural disaster.

According to the Law Number 24 of 2007 on Disaster Management, there are 3 types of disasters: natural disasters, non-natural disaster, and social disasters. Geographically, coastal areas are known as areas vulnerable to natural disasters. Gorontalo city is one of the earthquake prone areas in Indonesia and is tectonically located in the area of where two large plates, Pacific and Eurasian plates, meet. It is also situated in a location where micro plates are located [7]. According to the data from the BNPB in 2020, there are similarities in the threats of potential disasters between Palu 
City and Gorontalo City which include earthquake, tsunami, flood, landslide, and fires, both forest fire and land fire. With these similarities in potential natural disasters between the two coastal areas, disaster preparedness is needed at various levels of the community. This implies that preparedness is also needed in various industries including in the hospitality industry for cities located in coastal areas such as Palu and Gorontalo cities.

Emergencies may potentially occur in workplaces. These emergencies do not only include disasters but also include industrial hazards, including fire. Law No. 1 of 1970 on Indonesia Occupational Safety also stated that workplaces that have potential hazards and risks must have risk management and control in the workplace. This law also applies to those workplaces that are prone to fires, including workplaces in the hospitality industry, that often have to deal with fires. For example, a fire had destroyed three building blocks of a fivestar hotel in Palu City in 2013 [8]. Several fire incidents have also occurred in hotels in Gorontalo City. Another type of disaster that will bring a significant impact on the hospitality industry is health-related disasters, such as the current COVID-19 pandemic. According to data from the Indonesian Hotel and Restaurant Association (PHRI) The hotel and restaurant industry has lost nearly $\mathrm{Rp} 70$ trillion in revenue 2,000 hotels and 8,000 restaurants closed during the first three months of the outbreak, which started in March in Indonesia.

The hotel industry faces many challenges during emergencies and disasters, such as potential damage to buildings, casualties both from guests and workers, and the threat of business closure [9]. An exploratory research that included a survey of hotels in Canada in 2011 showed that almost all hotels that participating in the survey did not have an emergency plan [10]. This situation is actually in contrast with the fact that disaster and emergency management, both for disasters and industrial accidents, is a very crucial component of the tourism industry, including in the hospitality industry [11]. The initial step in the process of emergency response management implementation in the workplace requires a self-assessment to be performed by the company organization. This self-assessment includes assessment of the disaster and emergency mitigation, preparedness, response, and recovery [12]. In addition to the emergency response management, the resilience concept has also emerged in recent years. Aspects associated with establishing resilience should also be considered as items in the self-assessment. These aspects include business operation, disaster preparedness, marketing, labor, and government institutions [13]. The application of emergency management and resilience is a necessity for companies, including those working in the hospitality industry.

Currently, research on hospitality and tourism industries is more focused on the process of response and recovery rather than focusing on risk reduction, mitigation, and preparedness [14], Therefore it is necessary to do a study on these less discussed aspects through a mapping of the hospitality industry needs in terms of indicators of disaster and emergency preparedness level in areas with high-risk for emergencies and disasters.

Thus, this study aimed to assess the level of emergency and disaster preparedness in the hospitality sector in Palu and Gorontalo cities as cities located in the coastal areas of Sulawesi, which is known to be an area that is high risk for disasters and emergencies.

\section{LITERATURE REVIEW}

Disaster is defined as a serious disruption or disturbance of the functioning of a community or society at any scale that is caused by an adverse event that is a result of the interaction of exposure, vulnerability, and capability that will involve the loss and impact on humans, material, economic, and environment [15]. The disaster risk management cycle consists of four phases: Prevention/Mitigation and Preparedness phases in the pre-disaster stage, and Response and Rehabilitation/Reconstruction phases in the post-disaster stage. In the prevention/mitigation phase, efforts are made to prevent or reduce damage (such as by building dikes and dams to prevent flooding). Activities and measures to ensure an effective response is given to a hazard are referred to preparedness (for example, emergency response drills and public awareness campaigns) and are not intended to prevent a catastrophe. The response program covers activities such as rescue, first aid, firefighting, and evacuation activities. In the rehabilitation/reconstruction phase, disaster risk reduction considerations should become the basis for all activities in this phase. Taking appropriate actions based on the concept of disaster risk management in each phase of the disaster risk management cycle can reduce the overall disaster risk [16].

To be able to run a preparedness process, the organizations and community must be resilient. The concept of resilience, according to Bruneau and Reinhorn, comprises of the following four main properties:

1. Robustness: strength, or the ability of elements, systems, and other measures of analysis to withstand a given level of stress or demand without suffering degradation or loss of function;

2. Redundancy: the extent to which existing elements, systems, or other measures of analysis are substitutable, i.e., capable of satisfying functional requirements in the event of disruption, degradation, or loss of functionality;

3. Resourcefulness: the capacity to identify problems, establish priorities, and mobilize resources when conditions exist that threatens to disrupt some element, system, or other measures of analysis.

4. Rapidity: the capacity to meet priorities and achieve goals in a timely manner to contain losses, recover functionality, and avoid future disruption [17].

Several assessment tools have been used to assess preparedness, including the Asia Pacific Economic Cooperation-Tourism Risk Management (APEC Tourism Risk Management) and the Tourism Resilience Index. The risk management process in the APEC tourism risk management guideline was adapted from the A/NZS 4360-1999 standard. This guideline explains that the tourism industry should implement risk management both for the corporate organization and through their involvement in the communitybased disaster risk management in their area [18].

In addition to the APEC Tourism Risk Management, other tools can also assess the preparedness level of an organization. Tourism resilience index (TRI) is a tool developed for the field of tourism, including hospitality and used for self-assessment to explore whether the tourism and hospitality industry, both individually or as a regional group, can maintain operations at 
the time and after a disaster strikes. An assessment using these tools will help managers and business owners to develop a long-term action plan on disaster preparedness [13].

In brief, the theoretical framework drawn from this theoretical review is as shown in Figure.

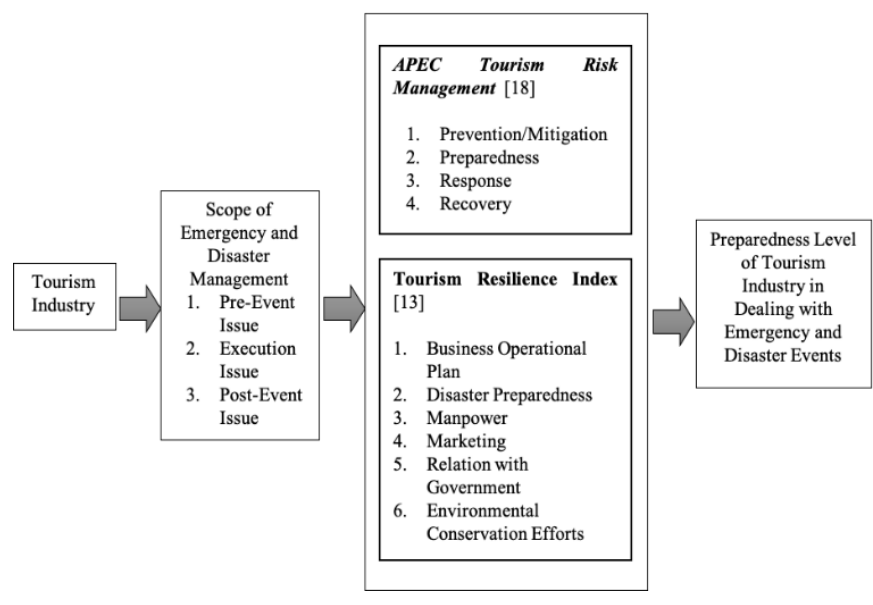

Figure 1. The theoretical framework drawn from this theoretical review

\section{METHOD}

This study was a cross-sectional quantitative-qualitative study on emergency and disaster preparedness levels in the hospitality industry in Palu and Gorontalo cities. The study population is the tourism accommodations in Palu and Gorontalo cities that include hotels and resorts, while the sample consisted of management representatives from these accommodations as the informants.

\subsection{Sample data and analysis}

The research was carried out in hotel sector located on the coast of Palu City, Central Sulawesi and Gorontalo, Gorontalo Province. The total number of hotels in Palu based on data from the Manpower Office of Central Sulawesi Province was 46, while the number of hotels in Gorontalo City based on data from the Local Central Statistics Agency in 2015 was 52 hotels.

Fifteen (15) hotels and ten (10) hotels in Palu City and Gorontalo City, respectively, were willing to participate in this study and assigned their company management as their representatives for data and information collection purposes. Data were then analysed using univariate analysis to describe the results of each factor or variables that influence the level of preparedness and also by using the multiple correspondence analysis to look at the sample position in the preparedness factor variable category by city. The qualitative data were analyzed using the content analysis method.

\subsection{Questionnaires, interviews, focus group discussions, and observations}

Data collection was performed using a questionnaire, observation, and secondary data collection. The questionnaire used was the APEC tourism risk management, tourism resilience index, which consists of eight variables, prevention/mitigation, preparedness, response, recovery, business plan, disaster preparedness, workforce, and relation with government. Primary data were obtained through closed questions with a choice of 0-4 scale scoring for prevention / mitigation, preparedness, response, and recovery by referring to a validated questionnaire issued by APEC Tourism Risk Management, while the variables for business operational plans, disaster preparedness, company relations with government agencies, and labor use closed questions in the form of Yes and No questions. In the variables of prevention / mitigation, emergency preparedness, response and recovery, the calculation of the scoring results is used to obtain the total score, then categorized on an ordinal scale to obtain a range of low, medium, and high categories, while the variables of business operational plans, disaster preparedness, company relationships with government agencies, labor, and standard assessment tools for the Tourism Resilience Index.

Expert validation was also involved in the preparation of this questionnaire. The experts involved include the National Disaster Management Agency (BNPB), the Ministry of Manpower, Emergency and Fire Specialists and Academics from the university. To enrich the research results, qualitative data was collected through focus group discussions and interviews with information from management representatives and the related government.

\section{RESULTS}

The results of the questionnaire were scored and the rating category was determined for each study variable. Univariate analysis was then performed to get the description of the frequency distribution of emergency and disaster management preparedness level variables. Figure 2 below is the scoring results for Palu City:

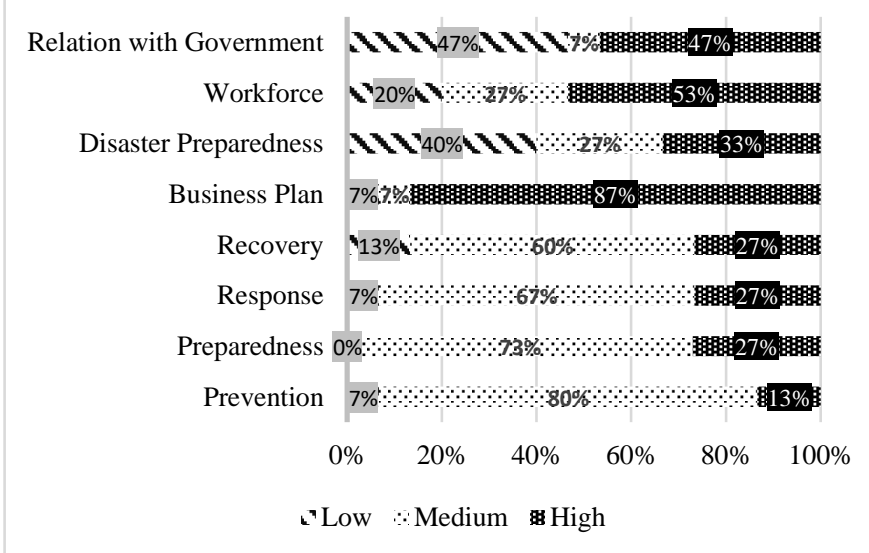

Figure 2. Number of hotels in level of preparedness category in Palu City

For the variables in the APEC Tourism Risk Management questionnaire as depicted in the chart, it was observed that $80 \%$ of the hotels in Palu City were in the medium category for prevention and mitigatiofn variable, while the other $13 \%$ and $7 \%$ were in the high and low categories, respectively. For the preparedness variable, $73 \%$ of hotels in this city were in the medium category and $27 \%$ were in the high category. No hotels were found to be in the low category for this variable. Results for the response variable showed that $67 \%$ of hotels in Palu City were categorized as medium, while $27 \%$ and $7 \%$ were in the high and low category, respectively. For the recovery variable, $60 \%$ of the hotels were found to be in the 
medium category, while $27 \%$ and $13 \%$ were identified to be in the high and low categories, respectively.

For the variables in the Tourism Resilience Index, it was revealed that for the business operational plan variable, most hotels were in the high category $(87 \%)$. The remaining $7 \%$ of the hotels were in the low and medium categories. As for the disaster preparedness variable, $33 \%$ and $27 \%$ of the hotels were in the high and medium categories while the remaining $40 \%$ were in the low category. For the workforce variable, $53 \%$ of hotels in this city were in the high category, while $27 \%$ were in the medium category and $20 \%$ were in the low category. In terms of government relation, $47 \%$ of the hotels in Palu City were categorized in the low category while $7 \%$ were in the medium category and the remaining $47 \%$ were in the high category. Low ratings in any of those variables, both from the APEC Tourism Risk Management questionnaire and the Tourism Resilience Index, indicate the needs for specific attention and immediate improvement efforts in the said variable. A medium category reflects the need of the company to make better efforts that the existing ones. In contrast, a high category reflects that the company is ready to face emergencies and disasters.

For Gorontalo City, the percentage of each variable studied is depicted in the following chart:

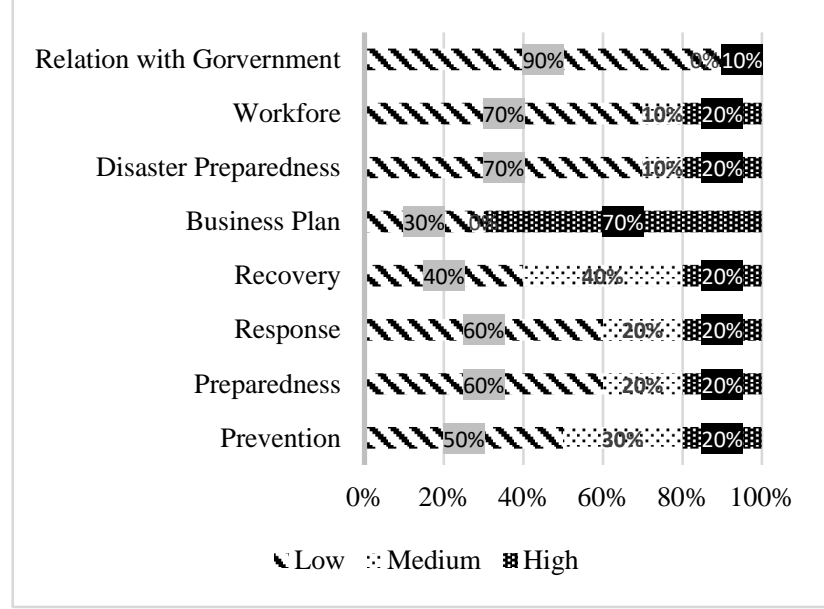

Figure 3. Number of hotels in level of preparedness category in Gorontalo City

Figure 3 presents variables from the APEC Tourism Risk Management questionnaire and the Tourism Resilience Index. For APEC Tourism Risk Management questionnaire, the chart shows that in terms of prevention and mitigation variable, $50 \%$ of the hotels in Gorontalo City were in the low category while $30 \%$ and $20 \%$ were in the medium and high categories, respectively. For the preparedness variable, it was identified that $60 \%$ of the hotels in this city were still in the low category. Only $20 \%$ of hotels were in the medium category, and the remaining $20 \%$ were in the high category. For the response variable, it was revealed that $60 \%$ of hotels were in the low category, while $20 \%$ were in the medium category and another $20 \%$ were in the high category. Forty percent of the hotels in Gorontalo City were in the medium category for the recovery variable, while $40 \%$ and $20 \%$ of the hotels were in the medium and high categories, respectively.

This study also analyzed the variables in the Tourism Resilience Index, and the results for Gorontalo Coty showed that around $70 \%$ of the hotels in this city were in the high category for the business operational plan variable. The remaining hotels were categorized in the low category for this variable. In contrast, in the disaster preparedness plan variable, $70 \%$ of hotels in this city were in the low category and only $20 \%$ were in the high category. The remaining $10 \%$ were in the medium category. A similar situation was also seen in the workforce variable. Seventy percent of the hotels in this city were in the low category, and only $20 \%$ were in the high category. The remaining $10 \%$ were in the medium category. For the government relation variable, $90 \%$ of the hotels in this city were in the low category and $10 \%$ were in the high category. Just like for Palu City, the variable categories should be interpreted as follows. The low ratings in any of those variables, both from the APEC Tourism Risk Management questionnaire and the Tourism Resilience Index, indicate the needs for specific attention and immediate improvement efforts in the said variable. A medium category reflects the need of the company to make better efforts that the existing ones. In contrast, a high category reflects that the company is ready to face emergencies and disasters.

To describe the correlation between the variables of the preparedness level between the two cities, a mapping with the Multiple Correspondence Analysis (MCA) approach using the SPSS software was performed. The categories from each study variables and the city location were entered into the SPSS 25.0 software to be able to create the map. The result of the mapping is presented in the column plot diagram below (Figure 4).

Dimension 1 depicts the rating category of each study variable, while Dimension 2 illustrates that the studied hotels by city. The mapping revealed that the hotels in Gorontalo City tend to be in the low category of preparedness level, while hotels in Palu City tend to be in the medium category of preparedness level.

Table 1 shows that there are two dimensions for mapping with MCA with a total eigenvalue of more than 1 and total percent variance is $92.1 \%$, which can be said with a twodimensional map of the mapping with this multiple correspondence analysis can explain as much as $92.1 \%$ of the variation in data. Cronbach's alpha value of 0.7 indicates that the data is reliable.

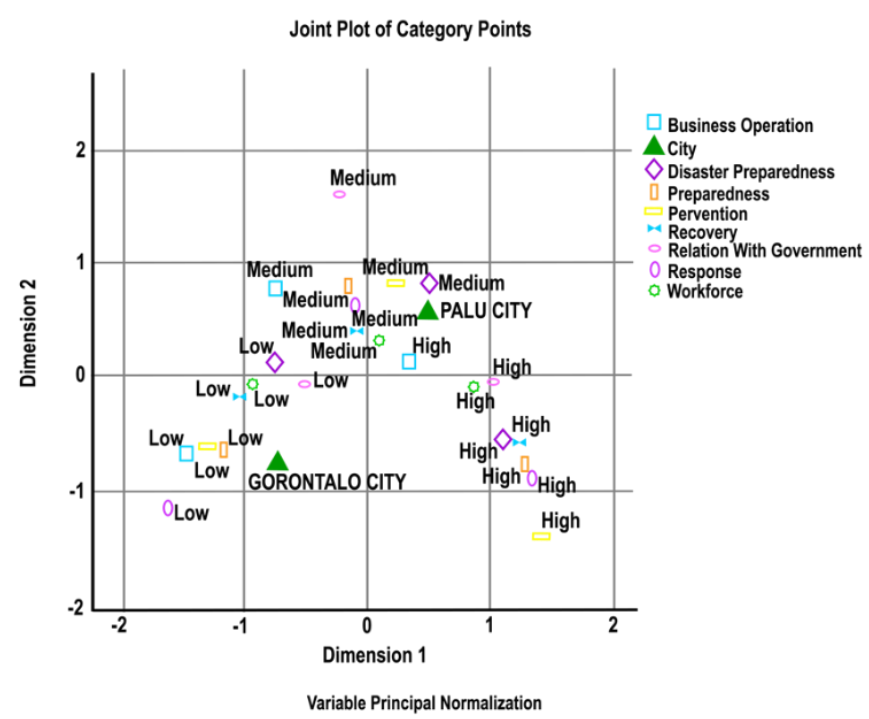

Figure 4. Multiple correspondence analysis chart 
Table 1. SPSS output multiple correspondence analysis

\begin{tabular}{ccccc}
\hline Dimension & $\begin{array}{c}\text { Cronbach's } \\
\text { Alpha }\end{array}$ & $\begin{array}{c}\text { Total } \\
\text { Eigenvalue }\end{array}$ & Inertia & $\begin{array}{c}\text { \% of } \\
\text { Variance }\end{array}$ \\
\hline $\mathbf{1}$ & 0.913 & 5.301 & 0.589 & 58.898 \\
$\mathbf{2}$ & 0.749 & 2.991 & 0.332 & 33.235 \\
& Total & 8.292 & 0.921 & 92.1 \\
\hline
\end{tabular}

\section{DISCUSSIONS}

\subsection{Overview of the implementation of emergency and disaster management}

In the APEC Tourism Risk Management guideline, the emergency management is divided into 4 (four) variables: prevention, preparedness, response, and recovery. In this study, it is obvious that the hotels in Palu City have a higher level of preparedness when compared to hotels in Gorontalo City. This difference might be associated with the experience of the management of these hotels. As widely known, hotels in Palu City have experienced a major disaster that the management becomes better prepared to face the possible emergencies and disasters in the future. In a study conducted by Brewer et al. in 2020 , it is suggested that the experience of dealing with a disaster not too long ago will affect the perception of preparedness in individuals, which then impacts the organization [19]. The experience of dealing with emergencies can directly influence the management to implement emergency and disaster management in the workplace. From the results of the focus group discussions, management also mentioned that the experience of facing a major disaster in 2018 has triggered the hotel management to consider implementing emergency management in the workplace.

The characteristics of the hotel also influence how the emergency and disaster management implemented. Most 1and 2-star hotels tend to neglect emergency and disaster management in the workplace. In a study conducted on hotels in tourist areas in Washington, United States, it was revealed that big hotels already have an emergency management for dealing with potential disasters and hazards compared to small hotels or hotels owned by individuals who do not have the program [20].

However, it is interesting to observe that in this study, a 2star hotel in Gorontalo city is in the high category in all four emergency management variables. During the observation and confirmation phase, it is understood that this hotel is a hotel under an Indonesian national franchise hotel as the sister company. The management representative of the hotel stated that the highest management influences the implementation of emergency and disaster management in the hotel. Faulkner in Disaster and Emergency Planning and Preparedness in Hotels (2001) stated that emergency management planning must consider several internal factors such as collaboration, communication, and control. However, the most important internal factor is the commitment of the management to adopt and develop an emergency management plan, which will be a strong guide in dealing with situations before, during, and after emergencies [21].

During the study, it was discovered that the hotels in Palu City that were involved in this study has begun to increase preparedness in dealing with emergencies and disasters related to earthquakes and tsunamis after they experienced a major disaster in 2018. This is documented in the results of the questionnaire and FGDs on items regarding the development of the emergency response plan in studied hotels. The recovery process that was performed by several hotels also began to take into account the safety aspects of building construction. In the hospitality industry in Gorontalo City, despite the fact that this city geographically has the potential for disasters that are similar to Palu City, it has not experienced a major disaster recently. This affects the preparedness level of the hospitality industry in Gorontalo City, other than the fact that most of the hotels studied in this city are 1-star hotels.

Analysis related to the 4 characteristics of the resilience concept proposed by Bruneu and Reinhorn [17] is the first is Robustness. From the results of the research conducted, the City of Palu has the strength to survive the threat of potential hazards by conducting an analysis to prevent the occurrence of the aftermath of the 2018 major disaster as a whole, starting from local to national governments including interventions in hotel organizations. Unlike the city of Palu, although the city in Gorontalo has never had a major disaster, this potential still exists due to the geographical location of the city of Gorontalo which is close to each other so that the potential for a great earthquake is still there. At the organizational level, this readiness is reflected in the availability of risk management which is only found in 3 and 4 star hotels in this study. Second concept of resilience is redundancy. Many hotels in these two cities have alternative sources of energy replacement during emergencies and disasters. However, substitutions related to energy sources are not enough. Hotel management needs to improve other vital alternative sources such as communication tools, water sources, food distribution so that resilience at the hotel organization level can be optimal. This is also closely related to the characteristics of the next concept of resilience, resourcefulness. Personal abilities also need to be improved so that workers can have the skills to save themselves, guests and mobilize resources. Not only that, organizations also need to set control priorities by building a system related to emergency and disaster, such as early warning system. For hotels with a small scale it is quite difficult to implement, the last analysis of the concept of resilience is Rapidity. The major disaster that occurred in Palu City made it difficult for hotel organizations to recover quickly. At the time of this research, many hotels in Palu City had not yet been able to open their businesses after one year. Hotels that have already run their operations explained through FGDs and interviews that they recover quickly because these hotels are responsive to make insurance claims and have minor building defect.

\subsection{Multiple correspondence analysis}

Based on the multiple correspondence analysis results, the hotels in Gorontalo city obtain a low category in almost all variables studied. This shows that hotels in Gorontalo tend to have a low preparedness level compared to hotels in Palu City that gain a medium category in almost all variables studied. In addition, it is also revealed that the majority of hotels in Gorontalo City participating in this study were 1-star hotels. The Focus Group Discussion result also displayed that it is difficult for hotels in Gorontalo to implement emergency and disaster management due to financial issues, lack of competence, knowledge, and poor relation with the government. In addition, hotels with the highest category, or high category, of preparedness level are 4-star hotels in both cities, as depicted in the column plots for the two cities. The mapping using the multiple correspondence analysis method enables us to see which variables need to be improved in both 
cities. It indicates that almost all variables of emergency and disaster preparedness need to be improved in Gorontalo City. Meanwhile, the government relation variable is the variable that needs to be improved in both cities.

\subsection{Hospitality industry preparedness in facing COVID-19}

According to the guideline issued by WHO on COVID-19 transmission prevention in hotels and accommodation, the hospitality industry should consider the manpower, guests, and facilities available at the hotel to prevent this disease to spread [22]. The hotel management's policy in dealing with the COVID-19 pandemic starts with implementing precautions in managing guests and workers to eliminate the spread of COVID-19 in the hospitality industry. Health protocols are then applied by checking the temperature for each guest, providing hand sanitizers, and wearing using masks. Disinfectant spraying is also performed in hotel facilities, such as the gym, public area, and hotel rooms on a regular basis.

Regarding the prevention of transmission among hotel workers, it was identified during the study that most of the hotels in Palu City reduced their on-shift employees and many hotels were even closed due to COVID-19. Some hotels also provide vitamins for improving the immunity of their employees who are still working in their shift. For the guests, hotels that are still operating provide handwashing facilities, hand sanitizers, and masks for hotel employees. Work shift arrangements and dissemination of knowledge to employees are also carried out as measures to prevent the spread of COVID-19 in the hotel area.

Government efforts to curb the spread of COVID-19 infections in the hospitality industry is done through the local tourism office that disseminates the health protocols that should be applied in this industry during the COVID-19 pandemic. In addition, the Health Office also regularly records and checks the health of the guests who are still staying at the hotels. Some hotels also obtain their disinfectant spray from the local Health Office. In terms of the employees, the local Manpower Office also collects data on workers who lost their job and affected by the COVID-19 pandemic. The obstacle faced by the local government in implementing the prevention actions is the lack of synergic coordination between the central government and the local government. According to several informants, hotel management has become more proactive in improving relations with the government during the COVID19 pandemic because they see that the business continuity can only be achieved if the hotels run their business in line with the government policy. Thus, the spread of coronavirus infection can be controlled in the hospitality industry.

\section{CONCLUSIONS}

The implementation of emergency and disaster management is necessary for various business sectors including in the hospitality industry. According to the disaster management cycle of prevention/mitigation, preparedness, response, and recovery, it is a requirement that the preparedness level assessment in the hospitality industry is done from the organizational level. In addition, additional factors such as business operational plan, manpower, disaster preparedness, and government relation also link to the preparedness factors.

Based on the results of the preparedness level assessment at the organization level of the hotel industry using APEC Tourism Risk Management and Tourism Resilience Index (TRI) in Palu City, the business operational plan variable of the hotels in the city is in the high category while the prevention, preparedness, response, and recovery are in the medium category. In terms of the disaster preparedness plan and government relation variables, most of the hotels in the city are in the low category.

The results of the same assessment in Gorontalo City present a different result. Almost all research variables are in the low category for hotels in this city, with only the business plan operational variable is in the high category. The variable categories should be interpreted to understand how the hotel can improve. The low category indicates the needs for specific attention and immediate improvement efforts in the said variable. A medium category reflects the need of the company to make better efforts that the existing ones. In contrast, a high category reflects that the company is ready to face emergencies and disasters.

The multiple correspondence analysis of emergency and disaster management preparedness factors also shows that hotels in Palu City are mostly in the medium category while those in Gorontalo City are mostly in the low category for all study variables. By inserting this into the same column plot, analysis and prioritization of the preparedness variable development can be facilitated for both cities

\section{ACKNOWLEDGMENT}

This study was supported by grants from Research and Community Engagement Directorate (DRPM) Universitas Indonesia No. NKB-0592/UN2.R3.1/HKP.05.00/2019.

\section{REFERENCES}

[1] ILO. (2011). Panduan Pengentasan Kemiskinan Melalui Sektor Pariwisata. International Labour Organization, Geneva.

[2] Antara. (2018). Pariwisata Banten terancam suram pasca-tsunami. [Online]. Available: https://www.antaranews.com/berita/782718/pariwisatabanten-terancam-suram-pasca-tsunami, accessed on 29 Agustus 2019

[3] BNPB. (2018). Kerugian dan Kerusakan Dampak Bencana di Sulawesi Tengah Mencapai 13,82 Trilyun Rupiah. [Online]. Available: https://www.bnpb.go.id/kerugian-dan-kerusakandampak-bencana-di-sulawesi-tengah-mencapai-1382trilyun-rupiah, accessed on 8 September 2019.

[4] Kemenpar. (2019). Kajian Dampak Sektor Pariwisata Terhadap Perekonomian Indonesia. Lembaga Penyelidikan Ekonomi dan Masyarakat FEB UI, Depok.

[5] Republika. (2018). TCC Kemenpar: Lebih dari 250 Kamar Hotel Terdampak Gempa. [Online]. Available: https://www.republika.co.id/berita/nasional/umum/18/0 9/29/pfsso2280-tcc-kemenpar-lebih-dari-250-kamarhotel-terdampak-gempa-part1, accessed on 19 April 2020.

[6] RRI. (2018). Perlindungan BPJS Ketenagakerjaan untukKorban Gempa di Palu. [Online]. Available: http://rri.co.id/post/berita/583607/press_release/perlindu ngan_bpjs_ketenagakerjaan_untukkorban_gempa_di_pa 
lu.html, accessed on 8 September 2019.

[7] Nurfitriani, Pasau, G., Raharjo, S.S. (2014). Identifikasi sesar di wilayah gorontalo dengan analisis mekanisme bola fokus. JURNAL MIPA UNSRAT ONLINE, 3(1): 40-43.

[8] Liputan6.com, "Hotel Sutan Raja Kebakaran, Api Merembet Ke Kios," 2013. [Online]. Available: https://www.liputan6.com/news/read/525242/videohotel-sutan-raja-kebakaran-api-merembet-ke-kios, accessed on April 182020.

[9] Lamanna, Z., Williams, K.H., Childers, C. (2012). An assessment of resilience: Disaster management and recovery for greater New Orleans' hotels. Journal of Human Resources in Hospitality \& Tourism, 11(3): 210224. https://doi.org/10.1080/15332845.2012.668653

[10] Gruman, J.A., Chhinzer, N., Smith, G.W. (2011). An exploratory study of the level of disaster preparedness in the canadian hospitality industry. International Journal of Hospitality \& Tourism Administration, 12(1): 43-59. https://doi.org/10.1080/15256480.2011.540980

[11] UNEP, DISASTER RISK REDUCTION: A Toolkit for Tourism Destinations, Paris: United Nations Environment Programme, 2008.

[12] Wayland, B.A. (2015). Emergency Response Planning Factors. Emergency Preparedness for Business Professionals : How to Mitigate and Respond to Attacks Against Your Organization, Elsevier Science \& Technology, 27-29. https://doi.org/10.1016/B978-0-12802384-6.00002-3

[13] Swann, L., Tracie, S., Colette, B., Chandra, W., Jody, T. (2015). Tourism Resilience Index: A business selfassessment. MASGP-15-007-02.

[14] Richie, B. (2008). Tourism Disaster Planning and Management: From Response and Recovery to Reduction and Readiness. Current Issue in Tourism, 11(4): 315-348. https://doi.org/10.1080/13683500802140372

[15] UNISDR. (2017). Terminology. [Online]. Available: https://www.unisdr.org/we/inform/terminology, accessed on 10 September 2019.

[16] Asian Disaster Reduction Center. (2005). Total Disaster Risk Management - Good Practices -. [Online]. Available: https:/www.adrc.asia/publications/TDRM2005/TDRM _Good_Practices/PDF/PDF-2005e/Chapter2_2.2.pdf, accessed on 13 Juni 2019.

[17] Bruneau, M., Reinhorn, A. (2006). Overview of the resilience concept. Proceedings of the 8th U.S. National Conference on Earthquake Engineering, California.

[18] APEC. (2006). Tourism risk management: An authoritative guide to managing crisis in tourism. APEC International Centre for Sustainable Tourism (AICST), Singapore.

[19] Brewer, C.A., Hutton, A., Hammad, K.S., Geale, S.K. (2020). A feasibility study on disaster preparedness in regional and rural emergency departments in New South Wales: Nurses self-assessment of knowledge, skills and preparation for disaster management. Australasian Emergency Care, 23(1): 29-36. https://doi.org/10.1016/j.auec.2019.12.005

[20] Johnston, D., Becker, J., Gregg, C., Houghton, B., Paton, D., Leonard, G., Garside, R. (2007). Developing warning and disaster response capacity in the tourism sector in coastal Washington, USA. Disaster Prevention and Management, 16(2): 210-216. https://doi.org/10.1108/09653560710739531

[21] Albattat, A.R., Matsom, A.P. (2019). Disaster and Emergency Planning and Preparedness in Hotels, 01 ed., Emerald Publishing Limited.

[22] WHO. (2020). Operational considerations for COVID19 management in the accommodation sector. [Online]. Available:

https://apps.who.int/iris/bitstream/handle/10665/331638 /WHO-2019-nCoV-Hotels-2020.1-eng.pdf, accessed on 09 May 2020. 